quick in their movements, which increased the difficulty of observation, but that the bees themselves were the agents, in making the holes, there can be no reason to doubt.

Highfield, Gainsborougb, December 21 F. M. BURTON

\section{Photography Foreshadowed}

THE first pruphetic allusion to the photographic art, the dis. covery of which was to take place eighteen centuries later, is perhaps found in the story of the miraculous occurrence told in the life of St. Veronica.

The second instance is about the year 1690 ; but intcrmediate instances may probably be found. 1 extract from the works of Fénelon 1 the lollowing passage from an imaginary voyage in 1600 :- "There was no painter in the colintry, but when any. one wished to have the portrait of a friend, a beautiful landscape, or a tabicau which represented any other object, he put water in large basins of gold or silver; then placed this water opposite the ohject he wished to paint. Soon the water congealing became like a looking-glass, in which the imagre of that object remained ineffaceable; and it was a picture as faithitul as the brightest mirrors." One could wish that the author had entcred into detail as to the manner "of placing this water opposite the ubjects he wished to paint."

The third instance is about 1760 , that is seventy years later, and seventy-nine years before 1839 , the date of Daguerre's dis covery. It is reported ${ }^{2}$ by Ed. Fournier, who extracted from what lie calls "un assez mauvais livre," written by a certain 'Tuphaigne de la Roclie ${ }^{3}$, the entire passage, ex'remely curious, but rather long. 'This passage contains many details. The "water" of Fćnelon is replaced hy " a material yery su'stie, very viscous, and very reary to dry and harden." "They" (cerrain "elementary spirits") coat with this material a piece of linen, and present it io the objects which they wish to pain:, " \&c.

In the two last examp es the pictures formed regroduce the iniages of the objects, with their natur.l colours and their forms, o that the objects are seen as if rellected in a mirror. The photographs of the present day are still very far jrom this ideal periection, which, however, they will probajly never cease to approach without ever being able to reach.

Rotte!dam

\section{J. A. Groshins}

\section{Average Annual Temperature at Earth's Surface}

HAVING lived for many years both in the solithern and rorthern hemispheres, I have a very strong impression that if means were taken to ascertain, with more or less approximation, the average annual temperaiure at the carth's surface, by a com. bination of the daily averiges of a sufficient number of places of witetration, there would be found a very considerable differerce in the jearly values of the said average annual temperatures. But whether, on inçuiry, the re should prove to be a decided iifference or an absulute agreement between these averages, the fact in either case would surely be worth ascertaining, and could no: fail to be instructive. It might be objected that it wouid be impossible to obtain the observations of the daily average tempe:a:ure from such a number of observatories as would render the desired arnual average for the whole earch of any value, but I think this objection overstates the difficulty. Suppose that the subject were taken up by some one of the meteorological authorities in Great Britain, it would not be difficult to obtain from existing daily records, a good average anuual value for the temperature of the Brttish Islands. Similarly, an average ammual value could be obtained for the temperature, from the daily averages in the various colonies and dependencies of the British unjire; and I take it to be certain, that the conductors of the various meteorolugical observatories all over the empire would clieeffully respond to an invitation to co-operate in such a work. In a similar scientific spirit it is to be hoped that the observatories of all civilistd countries would be willing to exchange their ubservations, and an approximate result cuuld thus be arrived at, possibly in two or threc years. Certainly, it might be at first a rough approximation only, but it would be yearly becoming letter with the rapid increase of meteorological observatories all over the world. And as it is nut too much to hope that, sooner or later, the whole habitable earth will be civiiised and covered with observatorfes, it is certain that the figures ultimately obtained to represent the average annual teniperatures at the earth's surface

\& Paris, Auguste Desrez, $18_{37}$, tome 2'me, p 643.

2 Le Vicux Neuf, Histoire Ancienne des lriventions et Découvertes Moderncs Y'aris, Dent11, 1859 .

3 Giphantic, a Baby!one, MDCCLX., $12^{\circ}$. would have the value of scientific approximations of considerable accuracy. If this be so, it cannot be ton early to begin these statistics now.

Supposing that these annual averages should exhitit a differ. ence in their yearly values, it is probable that these differences would vary in sympathy with the total sun-spot areas of the years to which they belonged. What could be done for temperature, could be done at the same time for other subjects of meteorological investigation, and it is impossible to anticipate at present what light these tabulated annual averages might be able to throw upon various problems of solar and terrestrial physics.

Balham, December 4

D. Traill

\section{ON A MEANS FOR CONVERTING THE HEAT:-} MOTION POSSESSED BY MATTER AT NORMAL TEMPERATURE INTO WORK

I $\mathrm{N}$ a previous article ${ }^{1}$ we considered how, by a simple mechanical means, diffusion renders it possible to derive work from malter at normal temperature. As the subject is an important one we propose to develop it somewhat further here.

2. The normal tempcrature of objects on the eartin's surface represents a vast store of energy in the form of molecular motion. The sea (for example) at normal temperature possesses an amount of molccular energy which (by computation), if it were entirely utilised, would be competent to lift it to a height of upwards of seventy miles. The air and the crust of the earth itself possess comparabic amounts of energy. It might thereiore well be asked beforehand whether it is not possible to transfer some of this intense molecular motion io masses and utilise it. It may be observed that this intense store of energy is being continually dissipated in space in the form of waves (by radiation;. 'The energy possessed by the molecules of matter, however, maintains (as is known) a constant normal value on account of the waves of heat received from the sun, whose mechanical value at the earth's surface (as represented by the results of Herschel and Pouillet) is normally equal to about one-horse poiver per square yard of surface. Here, therefore, we have a continual store of motion kept up in the nolecules of matter on the earth's surface to be wasted in yreat part in imparting motion to the ether of spacc. It would certainly look, dy priori, as if there ought to be some means of utilising this store of motion.

3. The second law of thermodynamics would (as is known) assume that this would not be practicable. This law was propounded simply as what was considered a legitimate inference from the observed behaviour of heat. But a great advance in the knowledge of the nature of heat has been made since that time, and it should be noticed that the law is (admittedly) by no means theoretically necessary or requisite to satisfy the principle of the conservation of energy. Indeed a conceivable case opposed to it has been pointed out by Prof. Maxwell, though one not capable of being practically carried out. It was my purpose in the last article to direct attention to a physical process opposed to the law and admitting of practical realisation, in the cffects attendant on the diffusion of matter. At the time when this law was enunciated the character of the motion termed "heat" (as illustrated in the now accepted kinetic thcory of gases) was unrecognised, and therefore the mechanism of the diffusion of gases was not understood. Under these conditions, therefore, it would not be much a point for surprise if increase of knowledge should show the law not to be generally applicable (or not to admit of that general application which is implied by the use of the term "la 0 ").

4. It may serve greatly to facilitate the following of this subject if we visualise the relations of heat and work more closely. Since "heat" is simply a nibtion of small portions of matter (termed "molecules"), and since the " "On the Diffusion of Matter in Re!ation to the Second Law of Thermo. d) namics," see Nature, vol. xvii. p. $3 x$. 